PEREIRA, Luiz C. Bresser. Construindo o Estado republicano: democracia e reforma da gestão pública. Rio de Janeiro: Editora FGV, 2009.

\title{
Da administração pública burocrática à gerencial
}

\section{From BUREAUCRATIC PUBLIC ADMINISTRATION TO MANAGEMENT}

\author{
* Tiago Freire dos Santos
}

"Construindo o Estado republicano: democracia e reforma da gestão pública", do economista e cientista político Luiz Carlos Bresser Pereira, traz um conjunto de idéias no sentido de propor uma reforma profunda na gestão pública com base na redefinição dos papéis do Estado.

Ao criticar a gestão pública burocrática adotada pelo Brasil, o autor sustenta a idéia de que além da propriedade privada e da propriedade estatal, há uma terceira forma de propriedade relevante para o capitalismo moderno, relacionando tal concepção à administração eficiente e gerencial da organização do Estado.

Assim, indaga quais as atividades ou papéis exclusivos que o Estado brasileiro deveria desempenhar, distinguindo das atividades sociais e científicas que tem interesse em financiar, mas não executar diretamente, e da produção de outros bens e serviços de mercado.

$\mathrm{O}$ autor sugere que, além das atividades exclusivas desempenhadas pelo Estado, ações estas que visam garantir diretamente que as leis e as políticas públicas sejam cumpridas e financiadas, executada pelo núcleo estratégico estatal através de propriedades estatais, há atividades não exclusivas que devem ser executadas por organizações públicas não estatais e privadas.

As organizações públicas não estatais são financiadas pelo Estado e orientadas para o interesse público, mas não fazem parte da máquina estatal, adotando a forma de empresas privadas, bem como não respondem diretamente aos chefes dos poderes do Estado, além do fato de que o seu pessoal não é composto de servidores públicos estatutários.

Assim, para o Autor é fundamental distinguir aquelas atribuições exclusivas do Estado que envolvem o uso do poder estatal (definição de leis e políticas públicas, imposição e arrecadação de tributos, manutenção da ordem pública e garantia da justiça etc.) daquelas atividades não exclusivas, embora, por escopo,

\footnotetext{
* Mestre em Direito Negocial pela Universidade Estadual de Londrina. E-mail: tiagofreire@onda.com.br
} 
definam o Estado socialdemocrático e o Estado social-liberal, particularmente os serviços sociais e científicos básicos e a produção de bens e serviços.

Segundo o autor, os serviços sociais, culturais e científicos (escolas, universidades, hospitais, creches, museus, rádios etc.) devem ser dirigidos pelos princípios gerenciais e não devem ser realizados diretamente pelo Estado, mas executados através de organizações públicas não estatais contratadas.

Em última ratio, são atividades competitivas que não devem ser tratadas como monopólios: não devem continuar no aparelho do Estado para serem executadas com eficiência. Isso porque para serem executados com eficiência, esses serviços exigem autonomia, impossível de ser assegurada dentro da máquina pública.

Insta registrar que para o autor há inúmeras razões para que o poder público financie esses serviços. O principal argumento econômico para justificar o financiamento parcial ou total é que esses serviços envolvem importantes externalidades positivas que, na maioria das vezes, não são devidamente remuneradas pelos mercados.

Na medida em que as organizações públicas não estatais são financiadas em parte ou totalmente pelo Estado, um dos mecanismos de responsabilização adotados deve ser a exigência de um contrato de gestão com o governo.

$\mathrm{Na}$ última linha tem-se a produção no mercado de bens e serviços, que devem ser na medida do possível transferida para a iniciativa privada através de privatizações, pois onde quer que exista a possibilidade de competição e sistemas de incentivos e punições de trabalhadores, os mercados são mais eficientes do que o Estado para coordenar as atividades.

Dessa forma, de acordo com o modelo de gestão pública proposto pelo autor, o Estado deveria, ele próprio, executar as atividades exclusivas do Estado. Os serviços sociais e científicos deveriam ser contratados com organizações sociais e, salvo algumas exceções, a produção de bens e serviços no mercado deveria ser executada eminentemente pela iniciativa privada. A proposta direciona-se para a obtenção de um modelo que assegure os direitos universais e disponha de um sistema desenvolvido de bem-estar social.

Luiz Carlos Bresser Pereira destaca que a reforma da gestão pública envolve a descentralização e delegação, para unidades subnacionais, de atividades e dos correspondentes recursos fiscais para financiá-las. Apenas assim é possível imprimir maior flexibilidade e eficiência na gestão pública e adaptá-la às demandas sociais. Segundo o autor, quando a descentralização se faz de acordo com os princípios da administração gerencial, envolvendo aumento 
da competição entre as organizações sociais, e mecanismos de controle como contratos de gestão e o controle exercido pela sociedade, estaríamos caminhando na direção desejada.

A proposta do autor tem o mérito de reunir na obra convincente fundamentação que sustenta a tese da necessidade de reforma da gestão pública para um modelo gerencial e atenua o choque que os teóricos têm ao se depararem com a idéia de reforma profunda na gestão pública.

Resenha recebida em: 25/02/2015 Aprovado para publicação em: 02/06/2015

Como citar: DOS SANTOS, Tiago Freire. Da administração pública burocrática à gerencial. Scientia Iuris, Londrina, v.19, n.2, p.244-246, dez.2015. DOI: 10.5433/2178-8189.2015v19n2p244. ISSN 2178-8189. 